\title{
Polypores rare in or new to Finland
}

\author{
TUOMO NIEMELÄ
}

\begin{abstract}
NIEMELÄ, T. 1981: Polypores rare in or new to Finland. - Karstenia 21: 15-20.
Antrodia onychoides (Egel.) Ryvarden, earlier known from the type only, is reported as new to Finland. Its emended description is given, and its taxonomic position discussed. A. ramentacea (Berk. \& Br.) Donk is reported from five localities in southern and south-eastern Finland, growing on corticated Pinus sylvestris. Gloeoporus gelatinosotubulosus (Pil.) Bond. ex Kartavenko has been collected from Finland for the first time, and the find is evidently the first outside the U.S.S.R. The species is briefly described, and its nomenclature is scrutinized. The occurrence of Inonotus dryophilus (Berk.) Murrill in Finland is substantiated, and earlier reports of the collections under the names $I$. dryadeus (Fr.) Murrill and $I$. hispidus (Fr.) Karst. are corrected. The species of Inonotus occurring in Finland are listed. Junghuhnia pseudozilingiana (Parm.) Ryv. is reported as new to Finland and Fennoscandia, and its identification and ecology are briefly discussed.
\end{abstract}

Tuomo Niemelä, Department of Botany, University of Helsinki, Unioninkatu 44, SF 00170 Helsinki 17, Finland

On the whole, the polypore flora of Finland is fairly well known, but changes and additions must certainly be made, before the picture becomes approximately complete. The tyromycetoid polypores, in particular, possess some difficult species groups, which, when thoroughly studied, may well prove to comprise more species than is realized at present. The troublesome groups are not treated in this paper, which deals, instead, with single species of relatively uncomplicated taxonomy. Since some of these are not well known, they will be described here in more detail.

The study is based on the collections deposited in H, HFR and TUR. Only dry herbarium material was used for the photographs and specific descriptions.

\section{Antrodia onychoides (Egel.) Ryvarden - Fig. 3 Polyporus onychoides Egeland}

Varsinais-Suomi. Turku, Ruissalo, on rotten deciduous tree (conf. Tuomo Niemelä), 1977 Vauras \& Vauras (H, TUR). Kustavi, Anavainen, dead Salix caprea, 1979 Alava 18886 (TUR).

New to Finland, and earlier known only from the type, which was collected near Oslo in Norway (Egeland 1913, Ryvarden 1976).

Fruit body annual, in initial stage often resupinate, later effused-reflexed or pileate, pilei solitary or more often imbricate. Consistency in dry state corky or hard corky, taste mild. Overall colour of dried specimens straw, pale yellowish or cream, pore surface slightly darker and lustrous, margin narrowly brownish when bruised. Pileus $3-15 \mathrm{~mm}$ wide, projecting 2-10 $\mathrm{mm}$ from substrate, up to $2 \mathrm{~mm}$ thick, wide-based to flabelliform, inrolling when drying. Upper surface smooth, under lens matted, with no pellicle or crust. Margin thin, acute, entire. Effused part formed by roundish patches which later fuse together and then up to $20 \times 20 \mathrm{~mm}$ wide, margin of effused parts regular or sinuous, distinct, with sterile, $0.5-1 \mathrm{~mm}$ wide border. Pores (5-) 6-7 (-9) per mm, roundish or angular, pore surface even or very weakly dentate, tubes up to $1.5 \mathrm{~mm}$ long; dissepiments very thin, $0.02-0.04 \mathrm{~mm}$ thick. In section context up to $1 \mathrm{~mm}$, subiculum $0.1-0.2 \mathrm{~mm}$ thick.

Hyphal system dimitic. Generative hyphae (2.2-) $2.8-3.2(-4.0) \mu \mathrm{m}$ in diam., thin-walled, rarely branched, without clamp connections. Skeletal hyphae prevailing in all parts of the fruit body, in hymenial trama $(2.2-) 2.5-3.0(-3.8) \mu \mathrm{m}$ in diam., in context and subiculum (2.8-) 3.5-4.0 (-4.7) $\mu \mathrm{m}$, thick-walled to subsolid, unbranched or with a few short terminal branches, in dissepimental trama very tightly interwoven, in context and subiculum more loosely so. Subhymenium indistinct. No 
cystidia or cystidioles. Hymenium with dense palisade of basidia and basidioles, soon collapsing. Basidia $12-15 \times 4.0-4.6 \mu \mathrm{m}$, basidioles $9-12 \times 3.2-3.8$ $\mu \mathrm{m}$, both without basal clamps, clavate, sterigmata four (seldom two) per basidium, 2.5-3.0 $\mu \mathrm{m}$ long. Spores (3.4-) 3.9-4.0 $\times(1.5-) 1.6-1.8 \mu \mathrm{m}$, cylindrical-ellipsoid, thin-walled, nonamyloid, indextrinoid, acyanophilous.

On dead broad-leaved trees, known from Fraxinus (type) and Salix caprea, causing white rot.

This description was based on the two Finnish collections and shows some differences from the good description of the type specimen published by Ryvarden (1976). The fruit body of the type is fragile (Ryvarden 1976), while the Finnish collections are somewhat sturdier, especially as regards the tube layer. Ryvarden mentions only the pileate state, while in the present material the effused-reflexed and resupinate conditions can also be demonstrated. This shows that the species (if the material is regarded as conspecific) is more plastic in morphology than can be concluded from the type material alone. In the type the pores are somewhat larger than in the material studied by me, thouth $t_{\mathrm{h}}$ ' measurements partly overlap. Some of these differtnces could be explained by the fact that the Finnisi collections represent a distinctly younger stage. The spore lengths of the Norwegian and Finnish colleciions agree well, but the spores are definitely narrower in the type $(1-1.5 \mu \mathrm{m})$ than in my material $(1.5-1.8$ $\mu \mathrm{m})$, a difference which is evident even from the spore form.

In spite of there differences, I am inclined to treat all these collections as conspecific. According to Ryvarden (1976), the combination of the dimitic hyphal system and the total lack of clamp connections is 'quite unique'. The collections of $A$. onychoides are evidently not yet adequate to reveal the total variation of the characters of the species. This concerns especially the features of the fresh fruit bodies.

The original material of Coriolus hoehnelii subsp. genistae Bourd. \& Galz. (Coriolus genistae (Bourd. \& Galz.) Bourd. \& Galz.) contains a specimen which should be mentioned here. The type and another collection of the type material are fibulate, but a third specimen ('sur genêt et bruyère, Chateau Charles (Allier), leg. H.B.') lacks clamp connections. The dimensions of its spores $(3-4 \times 1.5-2 \mu \mathrm{m})$ fit well with the spore measurements of the Finnish collections of $A$. onychoides. The details of this specimen are from Donk (1974). It may well be that it represents the fourth collection of $A$. onychoides. The name $C$. genistae is of much younger origin than
A. onychoides. I plan to return to these questions in a forthcoming study.

A. onychoides is not a typical representative of the genus Antrodia. Even if the lack of clamp connections is disregarded, there are some important features which separate this species from the rest of the genus. The chief of these is the fact that $A$. onychoides causes white rot, which to my mind is sufficient reason for removing it from Antrodia. The small spore size and the hyphal texture of the fruit bodies of $A$. onychoides also disagree with the characters of the genus. The species is listed here under Antrodia, because no better generic name is available for it. The most natural solution might be to include it in a new genus together with Trametes semisupina, $T$. hoehnelii, Poria romellii, Coriolus genistae and perhaps some underscribed species. [Addition November 1980: Ryvarden \& Johansen (1980) have described a new genus Antrodiella, with Polyporus semisupinus as the type.] $A$. onychoides is separated from the other species mentioned by the lack of clamp connections, but clear similarities are evident. Common features are the type of rot, the size and form of the spores, the hyphal construction, the type of basidia, the pale yellowish colouration, and also the general appearance of the fruit bodies. In fact, $A$. onychoides is easily mistaken for a small specimen of $T$. semisupina or $T$. hoehnelii, if the spore size and the septa in the generative hyphae are not carefully studied. By itself, the presence or absence of clamp connections does not appear to be a sufficient difference at generic level. For instance, the genera Albatrellus and Polyporus s.str. contain species of both types.

Antrodia ramentacea (Berk. \& Br.) Donk

Trametes subsinuosa Bres. - Figs. 1-2

Aland (Ahvenanmaa). Vårdö, Norrön, Pinus sylvestris, 1967 Olofsson (H); Söderön, P. sylvestris, 1967 Olofsson (H). - Etelä-Häme. Jaala, Karijärvi, P. sylvestris, 1964 Laine \& Poutanen 5438 (HFR). - Etelä-Savo. Anttola, Ikola, P. sylvestris, 1964 Laine \& Poutanen 5436 (HFR). Puumala, Kaijansalo, P. sylvestris, 1964 Laine 5437 (HFR).

According to the records listed, $A$. ramentacea is a rare species in Finland, being restricted to the southern and south-eastern parts. It grows mostly on young, scaly bark of Scots pine, causing brown rot on dead wood. Four of the collections showed effusedreflexed fruit bodies with appressed true pilei. The species evidently sometimes overwinters at least once. The effused parts of fruit bodies are separated from 

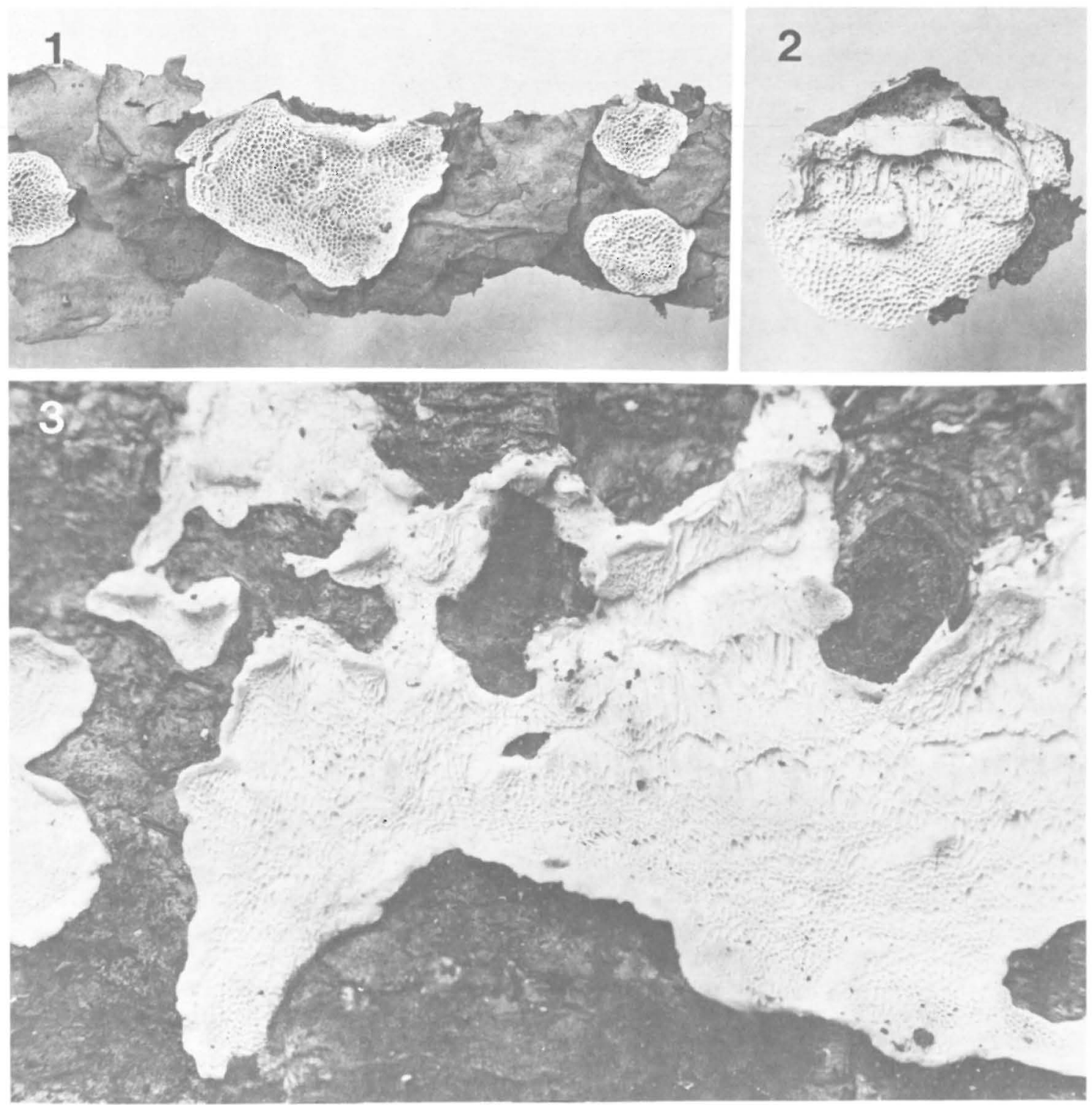

Figs. 1-3. Antrodia species. - 1: A. ramentacea, typical effused fruit bodies, $\times 1.3$ ( Aland, Vårdö, Norrön, 1967 Olofsson, H) . - 2: A. ramentacea, fruit body with reflexed parts, $\times 1.7$ (Etelä-Häme, Jaala, 1964 Laine \& Poutanen 5438, HFR). - 3: A. onychoides, effused-reflexed fruit body on bark of Salix caprea, $\times 4.5$ (Varsinais-Suomi, Kustavi, 1979 Alava 18886, TUR).

the similar $A$. heteromorpha by their thinner growth and more regular pores, the pileate parts by their less robust structure, smaller size, and thinner context (up to $0.6 \mathrm{~mm}$ ). Microscopically, A. ramentacea is easily distinguished from $A$. heteromorpha by its smaller spores and often thick-walled generative hyphae.

Gloeoporus gelatinosotubulosus (Pil.) Bond. ex Kartavenko. - Poria gelatinosolubulosa Pilát
Kuusamo. Taivalkoski, Kurtti, ?Pinus sylvestris, 1967 Laine, Wikström \& Niemelä 8282 (HFR).

New to Finland and Fennoscandia. Determined by Dr Erast Parmasto, Tartu. The specimen consists of poor fragments of a resupinate fructification attached to wood with extensive brown rot.

Fruit body very thin, resupinate, reticulate, when dry translucent whitish or cream-coloured. Pores angular, (1-) $2-3$ per $\mathrm{mm}$, dissepiments in dry state 

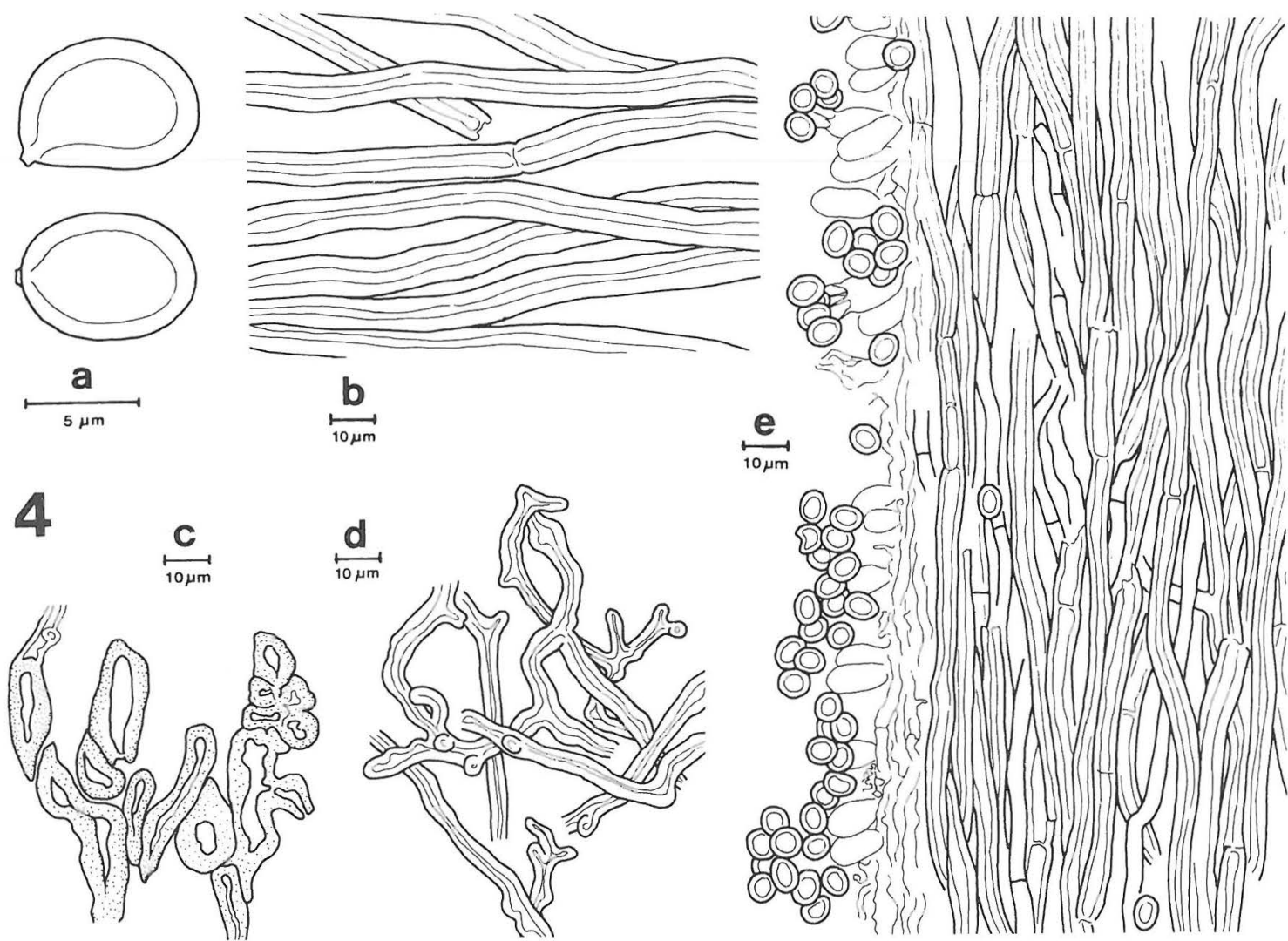

Fig. 4. Inonotus dryophilus: a) spores, b) parallel hyphae from context, c) fragments of core setae, d) tortous hyphae from core, e) dissepiment in vertical section (Varsinais-Suomi, Turku, 1936 Laurila, H).

very thin, fragile; subiculum almost absent. Monomitic, generative hyphae $(2-) 3.5-5 \mu \mathrm{m}$ in diam., hyaline, with clamp connections, with rather thin $(0.3-0.5 \mu \mathrm{m})$ walls, agglutinate and difficult to observe in Melzer's reagent, covered with delicate granular matter; walls thickening in $\mathrm{KOH}$. No cystidia. Spores ellipsoid-cylindrical, thin-walled, $4.2-5.0(-6.5) \times 1.9-2.1(-2.5) \mu \mathrm{m}$, nonamyloid, indextrinoid, acyanophilous or very weakly cyanophilous.

The Finnish material is not adequate for a complete description. Since Pilát (1936) described the species, this little known polypore has been mentioned in the literature only a few times. It was briefly redescribed by Pilát (1936-1942), under the generic name Poria. Bondarcev (1953) fransferred the species to the genus Gloeoporus, but failed to validate the combination by indicating the basionym (Code Art. 33.2). Kartavenko (1961) repeated the combination of Bondarcev, but also mentioned the basionym. (She referred only to Pilát 1936-1942, but this can be regarded as a bibliographic error (Art. 33.2, Example), and the original description can be traced through this reference.) Kartavenko thus validated the combination, although unintentionally, and the author's citation in the shortened form should be G. gelatinosotubulosus (Pil.) Kartavenko. The species was described later and in more detail by Parmasto (1963) and Stepanova-Kartavenko (1967).

According to these studies, G. gelatinosotubulosus has earlier been known only from the U.S.S.R.: from the Sverdlovsk and Tomsk Regions and the Komi A.S.S.R.

Inonotus dryophilus (Berk.) Murrill - Fig. 4

Varsinais-Suomi. Turku (Äbo), Ruissalo (Runsala), Quercus robur, Karsten 1757 (H), 1936 Laurila (H), 1974 Kallio (H, TUR).

Karsten (1889) recorded his collection as $I$. hispidus, but labelled the herbarium specimen Polyporus dryadeus. M. Laurila (in herb.) proposed 

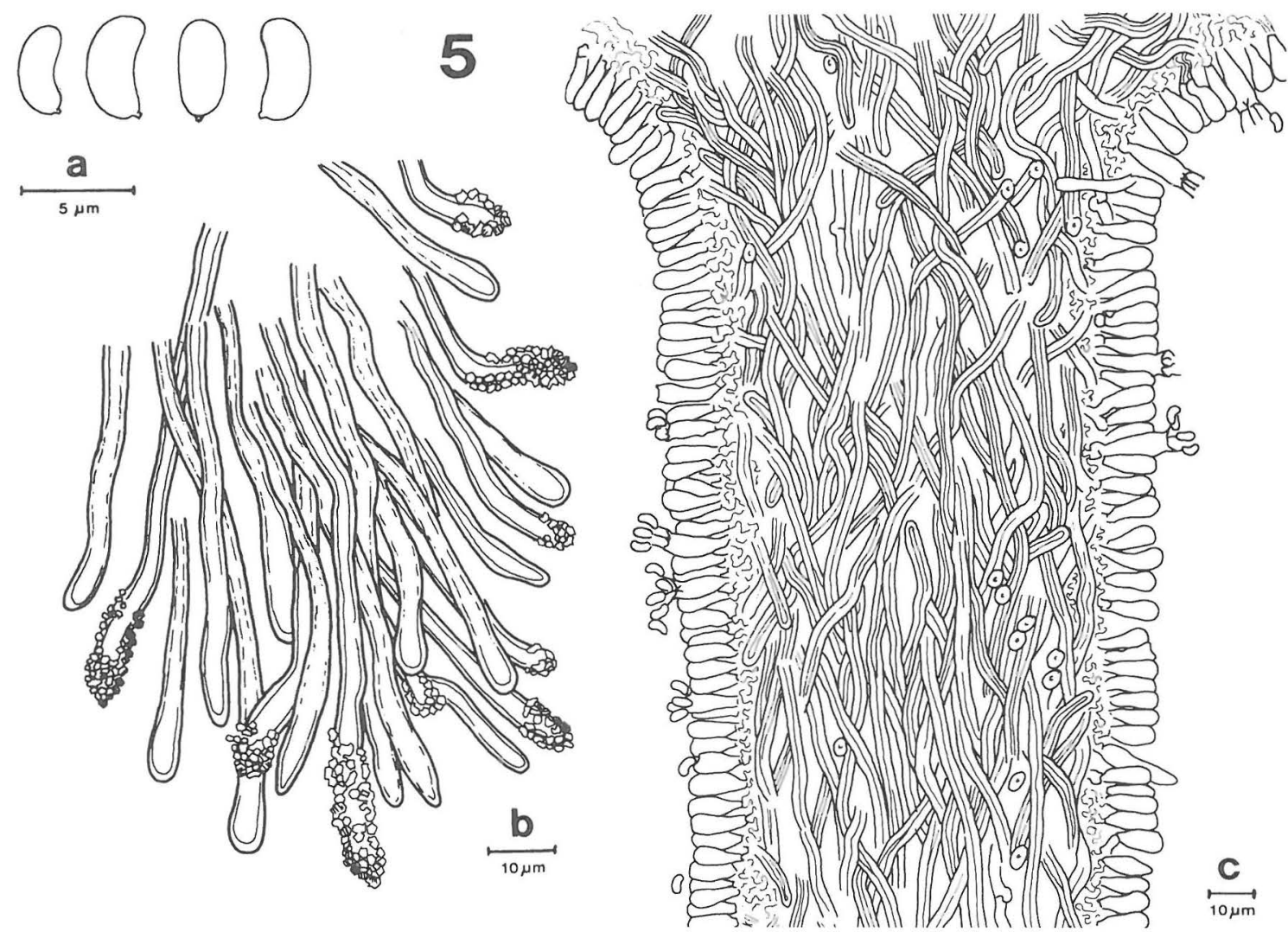

Fig. 5. Junghuhnia pseudozilingiana: a) spores, b) hyphal tips and cystidia from pore mouth, c) upper part of dissepiment in vertical section (Åland, Finström, 1965 Laine \& Kaivos 5840a, HFR).

the name I. hispidus for the specimen collected by him at the same locality. Kallio (1963) reported that this one Finnish occurrence was $I$. dryadeus. The specimens are, however, typical $I$. dryophilus, being ungulate, and having a large core, spores (7.5-) 7.9-8.0 (-8.3) × (5.2-) 5.5-5.7 (-6.1) $\mu \mathrm{m}$, and no setae (except core setae, $\mathrm{cf}$. the use of this term in Niemelä 1974), and growing high in the trunks of living oak trees (Kallio 1963). All the collections listed have been made in the same area, possibly from the same trees. My correction of the identification was accepted by Kallio (1979).

At present four species of Inonotus are known from Finland: I. dryophilus, I. obliquus (Fr.) Pil., I. radiatus (Fr.) Karst. and I. rheades (Pers.) Karst. The last three species are fairly common in the southern and central parts of the country, and scattered in northern Finland. In addition, a single collection of Inonotopsis subiculosa (Peck) Parm. (Inonotus subiluosus (Peck) Erikss. \& Strid) is known from northern Finland (Eriksson \& Strid 1969). No verified
Finnish records or herbarium specimens exist of $I$. cuticularis (Fr.) Karst., I. dryadeus (Fr.) Murr., I. hispidus (Fr.) Karst. or I. nodulosus (Fr.) Karst., in spite of some reports in the literature (Karsten 1876, 1882, 1889, Ryvarden 1978).

Junghuhnia pseudozilingiana (Parm.) Ryvarden

Chaetoporus pseudozilingianus Parmasto - Fig. 5

Alland (Ahvenanmaa). Finström, Pålsböle, Alnus glutinosa, on Inonotus radiatus (conf. Tuomo Niemelä), 1965 Laine \& Kaivos 5840a (HFR).

New to Finland and Fennoscandia. The identification was kindly confirmed by Dr. Erast Parmasto, Tartu.

Fruit body annual, resupinate or effused-reflexed, very irregular in shape. Consistency in dry state hard corky to brittle. Overall colour of dried specimen straw, dark cream or pale ochraceous. Largest specimen $24 \times 15 \mathrm{~mm}$ wide, at most $2.5 \mathrm{~mm}$ thick, reflexed part projecting $2-5 \mathrm{~mm}$ from substrate. 
Upper surface rough, with scattered, minute, conical spines (seen under a magnification of $\times 50$ ). Margin acute, entire or somewhat lobed. Pores (3-) $4(-6)$ per $\mathrm{mm}$, angular; tubes mostly ca. $1 \mathrm{~mm}$ long, mouths dentate; dissepiments very thin, $0.04-0.06$ $\mathrm{mm}$ thick. In section context $0.2-0.6 \mathrm{~mm}$ thick, subiculum $0.1-0.2 \mathrm{~mm}$.

Hyphal system dimitic. Generative hyphae $2-3 \mu \mathrm{m}$ in diam., thin-walled, branched, with clamp connections. Skeletal hyphae prevailing in all parts of fruit body, in hymenial trama $2-3 \mu \mathrm{m}$ in diam., in context and subiculum $2.5-4 \mu \mathrm{m}$, thick-walled to subsolid, unbranched, in dissepimental trama subparallel, in context and subiculum interwoven. Hyphae sometimes covered with granular crystals. Subhymenium ca. $5 \mu \mathrm{m}$, consisting of short-celled generative hyphae. Cystidia $18-23 \times 4.5-6.0 \mu \mathrm{m}$, clavate, formed by widened, rather thin-walled hyphal tips with long or capitate encrustation, rare to scattered, most common near tube mouths. Hymenium with dense palisade of basidia and basidioles, collapsing soon after sporulation, occasional hyphal pegs present. Basidia and basidioles $12-13 \times 4.5-5.0 \mu \mathrm{m}$, with basal clamp, clavate or cylindrical-clavate, sterigmata four per basidium, $3 \mu \mathrm{m}$ long. Spores (3.5-) 3.8-4.0 (-4.3) $\times \quad 2.0-2.2 \mu \mathrm{m}$, curved-ellipsoid, thin-walled, nonamyloid, indextrinoid, acyanophilous.

The above description is based on the only Finnish collection. Due to its cream colour and the growth on or near the fruit bodies of other polypores (Hymenochaetaceae), the species is easily confused with Trametes semisupina or T. hoehnelii. As pointed out by Parmasto (1959), bigger fruit bodies of $J$. pseudozilingiana may also resemble Oxyporus corticola (Fr.) Ryv. It is separated from these other species by the dimitic hyphal structure combined with the presence of cystidia.

According to Parmasto (1959), dead fruit bodies of Phellinus tremulae grown on Populus tremula are the typical substrate of $J$. pseudozilingiana. Betula pubescens has also been mentioned as a host, but this seems to be the first time that Inonotus radiatus on Alnus glutinosa is reported as the substrate. The species is not particularly rare in Estonia (Parmasto in litt. 1980), and may have been overlooked in Finland because of its small size and unappealing, irregular appearance.

Microscopically, J. pseudozilingiana is a typical member of the genus Junghuhnia (Chaetoporus).
Characters not found in the other species of this genus are the capacity to form true pilei and the tendency to grow on dead fruit bodies of other polypores.

Acknowledgements. I am indebted to Dr Erast Parmasto, Tartu, for the identification and confirmation of some critical specimens. The English of this paper was revised by Mrs Anna A. Damström, M.A. The work was supported by grants from the Academy of Finland, and the Jenny and Antti Wihuri Foundation.

\section{References}

Bondarcev, A. 1953: Trutovye griby evropejskoj ‘asti SSSR i Kavkaza. - 1106 pp. Moskva - Leningrad.

Donk, M. 1974: Check list of European polypores. - 469 pp. Amsterdam.

Egeland, J. 1913: Meddelelser om norske hymenomyceter 2. - Nyt Mag. Naturvidenskaberne 51: 53-93.

Eriksson, J. \& Strid, A. 1969: Studies in the Aphyllophorales (Basidiomycetes) of northern Finland. - Ann. Univ. Turku (A II) 40 (Rep. Kevo Subarctic Sta. 4): $112-158$.

Kallio, P. 1963: Zur Verbreitung einiger in Finnland südlichen Pilze, besonders in der südwestlichen Eichenzone. - Karstenia 6-7: 35-76.

- 1979: Ruissalo, luontoa ja kulttuuria. - 224 pp. Helsinki.

Karsten, P. 1876: Mycologia Fennica 3. Basidiomycetes. Bidr. Känned. Finlands Nat. Folk 25: 1-377.

- 1882: Rysslands, Finlands och den skandinaviska halföns hattsvampar 2. - Bidr. Känned. Finlands Nat. Folk 37: 1-257.

- 1889: Kritisk öfversigt af Finlands basidsvampar. Bidr. Känned. Finlands Nat. Folk 48: $1-470$.

Kartavenko, N. 1961: Redkie vidy gribov, obnaružennye na Urale. - Bot. Mater. Otdela Sporovyh Rastenij Bot. Inst. Akad. Nauk SSSR 14: 189-196.

Niemelä, T. 1974: On Fennoscandian polypores 3. Phellinus tremulae (Bond.) Bond. \& Borisov. - Ann. Bot. Fennici 11: 202-215.

Parmasto, E. 1959: Novyi vid roda Chaetoporus (sem. Polyporaceae). - Eesti NSV Teaduste Akad. Toimetised, Ser. Biol. 8: 113-117.

- 1963: K mikologiそeskoj flore Komi ASSR. - Tartu Riikliku Ülikooli Toimetised (Bot.-alased Tööd 6) 136: 103-129.

Pilát, A. 1936 ('1935'): Additamenta ad floram Sibiriae Asiaeque orientalis mycologicam 3. - Bull. Soc. Mycol. France 51: 351-426.

- 1936-1942: Polyporaceae 1-2. In: Kavina, C. \& Pilát, A. (eds.), Atlas des champignons de l'Europe 3. - 624 pp., 374 pls. Praha.

Ryvarden, L.. 1976: The Polyporaceae of North Europe 1. Albatrellus to Incrustoporia. $-214 \mathrm{pp}$. Oslo.

- 1978: The Polyporaceae of North Europe 2. Inonotus to Tyromyces. - Pp. 219-507. Oslo.

Ryvarden, L. \& Johansen, I. 1980: A preliminary polypore flora of East Africa. - 636 pp. Oslo.

Stepanova-Kartavenko, N. 1967: Afilloforovye griby Urala. -295 pp. Sverdlovsk. 